\title{
Osallistumistutkimuksen pienistä yksityiskohdista
}

\author{
"Tarvitaan tutkimusta, joka mittailee kulisseja, siis yhteiskuntaa, \\ ja sellaista joka katselee niiden lomasta, niissä ja niiden takana \\ liikkuvia ihmisiä... Kuka tietää, vaikka tätä kautta tietäisimme \\ tulevaisuudessa värikkäämmin jotain myös osallistumisen ilmiöstä."
}

Jukka Tuomisto $(1994,45)$ on äskettäin huomauttanut aiheellisesti siitä, että osallistumistutkimuksessakin pitäisi etsiä uusia ja mielenkiintoisia lähestymistapoja tutkia kohdettaan. Epäilyttäviä sivumerkityksiä herättävää sanontaa käyttäen osallistumistutkimuksessa olisi saatava aikaan rakennemuutos. Tässä yhteydessä kirjoittaja viittaa Mannisen (1989) ja Eskolan ja Suorannan (1993) juttuihin, joissa osallistumistutkimusta yritetään nähdä edes jossain määrin uudenlaisista menetelmällisistä ja teoreettisista näkökulmista.

Aina kannattanee pohtia kuitenkin sitä, mitä uudella missäkin yhteydessä tarkoitetaan. Kuten viimeksi (Suoranta 1994) olen yrittänyt vihjata, osallistumistutkimuksessakaan ymmärtävä tai laadullinen lähestymistapa, jossa kaikkein yleisimmin sanottuna osallistumista tutkitaan osallistujien omista lähtökohdista ja nämä pyritään ottamaan myös huomioon tutkimuksessa, ei sittenkään ole kovin uusi keksintö. Pikemminkin taitaa olla niin, ettei tämäntapaista tutkimusta ole vain nähty - eikä näin ollen paljon tehtykään - muilta menetelmällisiltä muodeilta ja metodologisilta uskomuksilta.

\section{Yksilöllisen ja yhteiskunnallisen ero}

Tuomiston (emt., 45) mukaan osallistumisen tutkimuksessa on nähtävissä kaksi pääsuuntaa, yksilöllinen ja yhteiskunnallinen. Jaottelu ei ole oikeastaan uusi eikä yllättävä toistaessaan sosiologian klassisen probleeman yksilön ja yhteiskunnan suhteesta. Yksilöllisen korvaisin kuitenkin tässä yhteydessä toiminnan käsitteellä yhteiskunnan vastinparina, metodologiseen individualismiin taipuvainen kun olen.

En silti väitä, etteikö kaikki yhteiskuntatieteellinen kerronta olisi pantu kokoon puheenparsista, joita sitovat yhteen yhteiskuntatieteellisen puheen konventiot aivan samoin kuin sitovat yhteen juuri sille tyypilliset sanonnat Tyrvään murteen. Minun on kuitenkin paljon vaikeampi käyttää oman tekstini kieliopillisena subjektina jotakin aikuiskoulutusinstituutiota tai vastaavaa kuin tällaisen instituution koulutustarjontaa käyttävää ihmistä. Vaikea on mieltää edes metaforana Tampereen työväenopiston ajattelevan, helppo sen sijaan olettaa tämä ominaisuus Pertti Timoselle.

Toisaalta, jos oma ajatteluni yhtäältä vieroksuu kollektivistisia käsitteitä, likvidoiden tekstistä referenttiä vailla olevat rakenteisiin viittaavat termit ja toisaalta rakenteisiin keskittyvä osallistumistutkimus tekee suunnilleen saman yksilön käsitteelle, ei sosiologian klassisen probleemin sanelemasta osallistumistutkimuksen umpikujasta päästä paljon pitemmälle.

Tehdään pari ajatuskoetta ja ajatellaan esitettyä vastakkaisuutta toisesta suunnasta. Ensinnäkin osallistumistutkimuksen trendejä voitaisiin alkaa peilata oleviin ja olleisiin yhteiskuntaohjelmiin. Nyt vaikuttaa nimittäin siltä, että tehtiin tällaista tai tuollaista osallistumistutkimusta, aina kuitenkin puhutaan yhdestä ja samasta yhteiskunnasta ikään kuin iäti muuttumattomana kokonaistoimijana.

jos tarkastelutapaan otettaisiin mukaan yhteiskunnan muuttuminen ja analyysia tihennettäisiin koskemaan pienempää yksikköä, olisiko silloin niin, että yhteiskunnan rakenteiden tasolla toimiva osallistumistutkimus teoreettisina malleineen kaikkineen nähtiin jonkun joukkoviestinnän tavoin moderniksi 
"keinoksi, jolla osaltaan pantiin toimeen rationaalisen yhteiskunnan suuri ja raskas rakennusprojekti. Sen avulla oli määrä johdattaa ihmiset käyttäytymään 'hyvin' ja omistautumaan ylemmille päämäärille." (Pietilä 1994, 59.)

Toisaalta taas yksilöllisen, tai paremminkin toiminnan tasolla, tehtävä tutkimus olisi osoitus jostain muusta, ei pelkästään sellaisesta alati toistellusta latteudesta kuin yksilöllistymisestä, vaan paljon vankemmasta jälkimodernista selänkäännöstä kaikille isoille jutuilla ja ylevälle, katsomisesta arkiseen ja alhaiseen. Edelleen analogiana viestinnän tutkimuksesta voitaisiin näin ollen ajatella, että yhtä vähän kuin viestinnällä on tässä (postmodernissa) tilanteessa yleisöä sanan yhtenäisiä joukkoja tarkoittavassa merkityksessä, on osallistumistutkimuksella tutkimuskohteenaan aikuiskoulutusjoukkoja, jonka käyttäytymisen frekvenssejä voitaisiin seurata kuin sopulikantojen vuotuisia vaihteluita tai muurahaisten massapsykologiaa. jos modernin suuri projekti olisikin ollut vain itseään ruokkiva monstrumi, olisi se jättänyt jälkeensä ainoastaan "miljoonittain merkityksiä antavia, mielihyvää etsiviä ja kokevia, välineitä käyttäviä ja ohjelmia valitsevia yksilöitä" (Pietilä emt., 61).

Tällaisten yksilöiden osallistumisesta näyttäisivät rakenneteoriat kalpean kuvan ja olisivat vähintäinkin auttamattoman moderneja. Voitaisiinko enää puhua edes yhteisestä asiasta,mutta yksilöllisistä tulkinnoista vai olisivatko osallistumisenkin lehdet jo kuolleet?

Osallistumistutkimuksen trendien näkeminen yhteiskuntatieteellisen tutkimuksen peruspolariteetin tavoin, tuo esille myös asian tieteenfilosofisen, etten sanoisi ontologisen, puolen. Voidaanhan ajatella niin, että tutkittaessa ihmisiä telineillä, toimijoita yhteiskunnan rakenteissa, ovat tutkimuskohteina eri ihmiset vaikkakin samat - kuin tutkittaessa heitä kutakin yksinään yksilöinä. Kysymys on ainakin tutkimuksen tematisoinnista: tällä tai tuolla tavalla tarkasteltuna ihmisestä saadaan paljolti erilainen kuva kuin näin tai noin. Mutta otettakoon edelliset mietteet siis vain ajatuskokeina.

\section{Avoimmuuden periaate ja lähiluvun menetelmä}

Yhtä individuaalisia kuin yhteiskunta, näyttävät olevan sen toimijoiden osallistumiselleen antamat selityksetkin. Ne eivät noudattele sen paremmin yksi- kuin monioikoisiakaan motivaatio- tai tarveselityksiä, vaan panevat pohtimaan mistä osallistumistutkimuksissa ylipäätään on kysymys. Otan yhden esimerkin tutkimuksesta, jossa selvittelimme aikuisten naisten osallistumisestaan antamia selontekoja (ks. Ahrio ym. 1992, 329-333). Tutkimuksesta on raportoitu toisenlaisesta näkökulmasta aiemmin (Eskola \& Weckroth 1994), mutta tutkimusaineisto on tulkinnallisesti sen verran loppumatonta, ettei se tyhjene yhdestä eikä kahdestakaan tematisoinnista.

Laadullista tutkimusta on usein syytetty teoriattomaksi tai teoriattomuudesta. Tässä yhteydessä on kuitenkin hyvä muistaa esim. aineistolähtöisen tutkimuksen (grounded theory) suhde aiempien teorioiden käyttöön ja niiden antiin. Yhtäältä kyllä myönnetään hyödylliseksi tutustua ja olla tietoinen aiemmasta teorianmuodostuksesta, tämähän on selvää, mutta toisaalta taas sanotaan, että jos tutkimuskohde tahdotaan edes periaatteessa nähdä siitä itsestään käsin, olisi tutkijan syytä pyrkiä mahdollisimman tyhjään tauluun, johon tutkimus kohteesta saatavat havainnot sitten piirtäisivät merkkinsä - mikä lienee havainnointimme luonteesta johtuen sula mahdottomuus. Tämä ei kuitenkaan voi estää yrittämästä olla tutkimuskohteelleen mahdollisimman avoin.

Tällaisella avoimmuuden periaatteella alkaa aineistonsa alkuun merkityksettömissä yksityiskohdissa nähdä johtolankoja siitä, miten osallistumismotiiveihin ja sentapaisiin selitysmalleihin tulee suhtautua. Avoimmuuden periaatetta sopii verrata alunperin Gilbert Rylen (1949), mutta sittemmin Glifford Geertzin (1973) esiintuomaan, ajatukseen tiheästä kuvauksesta. Ehkäpä tätäkin parempi vertailukohta on Gabriel Garcia Marquesin romaanissaan Sadan vuoden yksinäisyys esittämä kuvaus sokeutuvasta Ursula-äidistä (ks. Peltonen 1992. 31). Samalla kun menettää vähitellen näkökykyään, oppii hän perheensä arkipäivän toiminnat ja rutinoituneet käytännöt niin hyvin, ettei sokeutumista tarvitse muille edes tunnustaa.

Metodologisesti mielenkiintoista tässä on tietenkin se, että Ursula-äiti saattaa kertoa kadonneen esineen olinpaikan päättelemällä päivän mittaan tapahtuneista pienistä yksityiskohdista, muistelemalla milloin arkipäivän rutiini on rikkoutunut ja missä kohtaa kadonnut esine on ollut mahdollista kadottaa. - On 
mielenkiintoista, että avoimuuden periaatetta tai lähilukua aineiston analyysimetodina on vaikea kuvata muuten kuin edellä esitetyn tapaisten kertomusten kautta. Osallistumistutkimuksen rahoittajat onkin paljon helpompi vakuuttaa kertomalla kyselytutkimuksen standardimetodeista kuin määritellä lähestymistapansa sokeutuvan - puhumattakaan paranoikon (ks. Peltonen 1994, 5-6) - menetelmäksi.

\section{Yksilölliset tavat puhua}

Kokemuksen avoimmuuden periaatteesta, pienten yksityiskohtien mielenkiinnosta ja lähiluvun 'tekniikasta', sain lukiessani erään naisen selontekoa siitä, mitä aikuisopiskelu avoimessa korkeakoulussa oikeastaan merkitsee. Metodologisesti ja myös sisällöllisesti silmäni avautuivat haastattelujaksossa, jossa tulee esiin se, miten saman haastattelun aikana samasta asiasta kerrotaan erilaisia versioita lyhyessäkin ajassa. Millainen kuva opiskelun merkityksestä rakentuisi, jos tulkinta tehtäisiin ainoastaan näytteessä 1 ( $\mathrm{K}=$ kysymys ja $\mathrm{V}=$ vastaus) annetun vastauksen perusteella.

\section{Näyte 1}

K: No, tota mitä opiskelu on sulle merkinny?

$V$ : Se on ollu, joo, onks sulla niin pitkä nauha, että voi miettiäkin. (naurua)

K: Joo, joo mä voin kääntää sitte, kyllä saa puhua niin paljon kun jaksaa.

V: Tota noin (..) se on lähinnä se, se ei ammatillisesti merkkaa paljokaan, että se ei takaa mulle nousemismahdollisuuksia ilman mitään tutkintoo (.) Et enempi se meinaa mulle ittelleni ja mun itsetunnolleni ja (.) omalle kehittymiselleni (.) ja sillain se on ollu mulle tärkee, ja sit se, että se on (.) täys vastapaino mun työlleni, mä oon pitäny sitä niinkun harrastuksena.

Tässä näytteessä vastaaja rakentaa melko jyrkän vastakohdan opintojen ja työn välille. Ensinnäkin opiskelu ei merkkaa paljon ammatillisesti, koska se ei mahdollista urakehitystä ("nousemismahdollisuuksia"). Opinnot olisivat siis ammatillisesti merkitseviä vasta silloin, jos ne mahdollistaisivat etenemisen uralla. Toiseksi vastaaja vastakohtaistaa oman ja uralla kehittymisen. Enemmänkin opiskelu merkitsee ensinnäkin itselle ja itsetunnolle, toiseksi omalle kehittymiselle ja on kolmanneksi vastapaino työlle. Erityisesti näytteen loppu antaisi mahdollisuuden tulkinta koko vastausta siten, että opiskelu avoimessa korkeakoulussa olisi pääasiallisesti vapaatavoitteista ja harrastuksenomaista. Avoimmuuden periaate neuvoo kuitenkin lukemaan haastattelua edelleen. Seuraava näyte jatkuu suoraan edellisestä.

\section{Näyte 2}

K: Minkälainen vastapaino työlle?

$V$ : Mä teen nuorisotyötä ja se on niin harrastusluonteista, että siinä paljon, paljon tehään kaikkee mikä yleensä luetaan harrastuksen piiriin, niin sit kaipaa niinku jotain tämmöstä täyspainosta siihen rinnalle. (.) mun mielestä opiskelu on semmonen aika painava juttu, jos tämmöstä termiä voi käyttää (naurua).

K: Mitä sä tarkotat sillä painavalla?

$V$ : Siis semmonen (.) et siinä on hyvin paljon sisältöjä ja siinä on hyvin paljon ulottuvuuksia ja hyvin paljon mahdollisuuksia.

Haastattelun jatko näyttääkin riitauttavan ensiksi tehdyn tulkinnan. Otetaan vielä rinnakkain seuraavat katkelmat ensimmäisestä ja toisesta vastauksesta:

\section{Näyte 1}

[Opiskelu].. se on (.) täys vastapaino mun työlleni, mä oon pitäny sitä niinkun harrastuksena.

\section{Näyte 2}

$V$ : Mä teen nuorisotyötä ja se on niin harrastusluonteista, että siinä paljon, paljon tehään kaikkee mikä yleensä luetaan harrastuksen piiriin, niin sit kaipaa niinku jotain tämmöstä täyspainosta siihen rinnalle. (.) mun mielestä opiskelu on semmonen aika painava juttu, jos tämmöstä termiä voi käyttää (naurua). 
Näiden otteiden kautta alkaa ensimmäisestä vastauksesta tehty tulkinta peruskysymykseen, "No, tota mitä opiskelu on sulle merkinny?", vaikuttaa varsin ongelmalliselta. Ensimmäistä näytettähän saattoi lyhykäisyydessään tulkinta vielä siten, että se kertoi opiskelun olevan vapaatavoitteinen vastapaino työlle ja ennen muuta harrastus. Mutta toisessa näytteessä vastaaja merkityksellistääkin opiskeluaan uudella ja toisenlaisella tavalla. Asetelma keikahtaa itseasiassa lähes päälaelleen verrattuna aiempaan: nyt työ onkin "harrastusluonteista" ja opiskelu sitä vastoin "täyspainosta" ja "aika painava juttu". Viimeistään tässä vaiheessa haastattelu muuttuu mielenkiintoiseksi, eikä sen lukemista kannata lopettaa vielä tähänkään. Näytteessä 3 haastattelija kysyy aikuisopiskelun määrittelyä, mutta vastaaja jatkaa sinnikkäästi opiskelun merkityksen pohtimista.

\section{Näyte 3}

K: Miten sä määrittelisit sen korkeakouluopiskelun omalla kohdallas, siis niinku tän aikuisopiskelun, mitä se on ollu?

$V:$ (..) Se on ollu sitä, että vaikka mä nyt äsken sanoin, et se ei ammatissa auta eteenpäin, mutta se auttaa kumminkin mua ammatillisissa asioissa, siis se antaa mulle koko ajan jotain semmosta mitä mä voin käyttää joka päivä. ja sitten, vaikka, vaikka mä ajatteleen, että nää yliopistoympyrät (.) on (..) on hyvin jäykät ja kankeet (.) niin se on kumminkin semmonen toisenlainen sosiaalinen tilanne mulle kun mitä on työtilanne, (.) et se on tavallaan niinkun toinen maailma tää kokonaan tää opiskelumaailma. Mutkun mä täällä luennolla taikka teen jotain harjotuksia taikka muuta niin mä unohdan sen toisen puolen ittestäni.

Nyt vastaajan tarina alkaakin olla kuin toisesta haastattelusta; hän kertoo opiskelusta jo varsin toisin kuin näytteessä 1. Nyt aikuisopiskelun yksi merkitys onkin siinä. että se auttaa "ammatillisissa asioissa" ("se antaa mulle koko ajan jotain semmosta mitä mä voin käyttää joka päivä").Vaikkei se ehkä autakaan välittömästi uralla etenemisessä, antaa se kuitenkin päivittäin työssä tarvittavia ajatteluvälineitä.

Lisäksi opiskelu jäykissä ja kankeissa yliopistoympyröissä on kuitenkin "toisenlainen sosiaalinen tilanne" kuin "työtilanne". Opiskelu yliopistossa on "toinen maailma", jossa itsen työpuoli unohtuu. Tätä voi verrata näytteen 2 katkelmiin: "Mä teen nuorisotyötä ja se on niin harrastusluonteista" ... "sit kaipaa niinku jotain tämmöstä täyspainosta siihen rinnalle."

Haastattelua näin lähilukemalla ja keskittymällä sen pieniin yksityiskohtiin, näkyy kuinka lyhyessäkin katkelmassa samasta opiskelun merkityksen teemasta tuotetaan vastakohtaisia vastauksia. Aikuisopiskelun merkityksestä näytetään siis saatavan jo yhdenkin puhujan perusteella monta erilaista kuvaa. Yksi mahdollinen tulkinta puheen moninaisuudelle on tietenkin se, että juuri haastattelutilanne virittää puhujan antamaan tällaisia ja tuollaisia selontekoja. Lieneekin mielekästä olettaa, että se miten opiskelusta kerrotaan on pitkälle tilannesidonnaista. jossakin toisessa sosiaalisen elämän osakokonaisuudessa opiskelusta puhuttaisiin toisenlaisin äänenpainoin.

\section{Antaa kaikkien kukkien ...}

Edellisestä lähiluennasta on opittavissa ainakin se, että aikuisopiskelu merkityksestä kerrotaan sen mukaan mikä näyttäisi olevan sopivaa haastattelutilanteessa muotoutuvan vuorovaikutuksen aikana. Tätäkin tulkintaa voidaan katsoa ainakin kahtaalta. Yhtäältä saatetaan väittää, että kieliyhteisöjen sidokset tekevät ihmisistä marionetteja, jotka sätkyvät kulloisenkin kielellisen ärsykkeen mukaisesti. Toisaalta voidaan päätyä vastakkaiseen näkemykseen, etteivät ihmiset olekaan kulttuurin sätkynukkeja, vaan erityisen taitavia selviämään arkielämän moninaisista sosiaalisista labyrinteista ottamalla huomioon kulloisenkin vuorovaikutusnäyttämön puitteet. Jälkimmäisen tulkinnan mukaan sosiaalisen teatterin ohjaajiksi itseään luulottelevat ihmistieteilijät paljastuisivat lähemmässä tarkastelussa eivät paljoksi muuksi kuin yhden tällaisen näyttämön ylläpitäjiksi.

Liberaaliksi lopuksi sanottakoon kaikkien muidenkin nuorten vihaisten miesten muistoksi ja tulevien kiusaksi, että kaikenlaista osallistumistutkimusta tarvitaan. Tarvitaan sellaista, joka mittailee kulisseja, siis 
yhteiskuntaa, ja sellaista, joka katselee näiden lomasta, niissä ja niiden takana liikkuvia ihmisiä. Näin saavutetaan parikin etua. Ensinnäkin avartuu osallistumistutkimuksen vielä niukka menetelmällinen maisema ja kuka tietää, vaikka tätä kautta tietäisimme tulevaisuudessa värikkäämmin jotain myös osallistumisen ilmiöstä.

Toiseksi nähdään, ettei ole mieltä huudella ja kiistellä sellaisten metodologisten raja-aitojen yli, jotka eroavat jo perusoletuksissaan toisistaan. jos on niin kuten näyttää, että osallistumisesta annettuja selontekoja melkein vainoharhaisella mielenkiinnolla lukemalla, alkavat osallistumismotiivit ja inhimillisen toiminnan rakenneselitykset vähintäin rakoilla, ei kai ole mieltä ylläpitää hedelmätöntä ajatusta erilaisten menetelmällisten lähestymistapojen toisiaan täydentävästä luonteesta, vai onko? Eikö sittenkin ole mielekkäämpää ajatella lähestymistapojen eron olevan perustava ja olla suotta murehtimatta niiden osallistumisesta antamien kuvien tarkastelutasoisista eroista.

Tällöin käy turhaksi myös erilaisten menetelmien ja tutkimussuuntausten vertailu tyyliin 'tämä on hyvä tuo taas paha'. Sen sijaan sallittakoon ja suorastaan kehotettakoon kiistelyyn kulloisenkin tutkimussuuntauksen sisällä. Tässä yhteydessä viittaan vain Tuomiston (1994) ja Rinne ym. (1994) sanailuun, joka tarjoaa mukavaa vaihtelua muuten kuivakkaaseen tieteelliseen keskusteluun, jota ei muuten sitäkään harjoiteta murheeksi asti.

Vai olenko sittenkin ollut väärillä urilla astellessani vanhojen mestarien jäljissä ja toistellessani toiminnan/rakenteen, yksilön/yhteiskunnan vastakkaisia kategorioita. Pitäisikö juuri niitä alkaa purkaa tarkastamalla aluksi oman tekstin vastakkainasetelmia lähiluvun keinoin.

\section{LÄHTEET}

Ahrio, L., Eskola, J. \& Suoranta, J. 1992. Aikuisopiskelu - järjestelykysymys? Avoin korkeakouluopetus osana arkielämää. Teoksessa Eskola, J. (toim.) Puhetta opetuksesta ja opiskelusta. Tampereen yliopiston sosiologian ja sosiaalipsykologian laitoksen tutkimuksia A 23, 272-345.

Eskola, J. \& Suoranta, J. 1993. Uudistaisimmeko osallistumistutkimusta? Teoksessa Remes, P. (toim.) Aikuisen positiivinen koulutusvalinta: työssä vai koulussa oppiminen. Jyväskylän yliopiston kasvatustieteiden tutkimuslaitoksen julkaisuja B 78, 139-145.

Eskola, J. \& Weckroth, K. 1994. Puhetta harrastuksesta - avoin korkeakouluopiskelu opiskelijoiden kuvaamana. Aikuiskasvatus 14 (1), 36-41.

Geertz, G. 1973. The Interpretation of Cultures. New York: Basic Books.

Manninen, J. 1989. Aikuiskoulutukseen osallistuminen. Osallistumista selittävien mallien tarkastelua. Teoksessa Poikela, E. \& Tuomisto, J. (toim.) Aikuiskasvatuksen 1. tutkijatapaaminen-seminaariraportti. Tampereen yliopiston aikuis- ja nuorisokasvatuksen laitoksen julkaisuja 25.

Peltonen, M. 1992. Matala katse. Helsinki: Hanki ja jää.

Peltonen, M. 1994. Arjen historia asenteena. Tiedepolitiikka 19 (1), 5-9.

Pietilä, K.. 1994. Ajopuunkaltainen viestintätutkimus. Tiedotustutkimus 17 (2), 56-68.

Rinne, R.., Kivinen, O. \& Ahola, S. 1994. Eivätkö aikuiset kouluttaudu? Aikuiskasvatus 14 (2), 148-151.

Ryle, G. 1949. The Concept of Mind. London: Hutchinson.

Suoranta, J. 1994. Osallistumistutkimuksen metodologiaa purkamassa. Aikuiskasvatus 14 (1), 26-35.

Tuomisto, J. 1994. Uutta tietoa aikuisten opiskelusta. Aikuiskasvatus 14 (1), $42-51$. 